\title{
COMPARATIVE ANALYSIS OF RULES FOR SMOKE DETECTORS ARRANGEMENT IN CORRIDORS
}

\author{
UDC614.842.4:72.011.8
}

\author{
Milan Blagojević ${ }^{1}$, Radoje Jevtić ${ }^{2}$, Dejan Ristić ${ }^{1}$ \\ ${ }^{1}$ University of Niš, Faculty of Occupational Safety, Niš, Serbia \\ ${ }^{2}$ School of Electrical Engineering "Nikola Tesla", Niš, Serbia
}

\begin{abstract}
The aim of this paper is a comparative analysis of rules for arrangement and distribution of fire detectors in corridors and narrow places according to five leading standards for fire detection systems design in the world: EN 54-14, VDE 0833-2, BS 5839-1, НПБ 88 and NFPA 72. The reason for such analysis is obvious - the European standard does not define the corridor, only the narrow rooms are mentioned, but the other standards precisely define the term corridor as well as the rules for siting and spacing of point fire detectors. The comparative analysis is made by means of simulation model using PyroSim software, version 2012, which presents a graphical user interface for the Fire Dynamics Simulator (FDS).
\end{abstract}

Key words: point smoke detectors, corridors, simulation model, PyroSim

\section{INTRODUCTION}

The European standard EN 54 Part 14 Guidelines for planning, design, installation, commissioning, use and maintenance is mandatory for fire alarm system designers in Europe, but there are many situations that this standard does not cover at all.

German standard VDE 0833 Part 2 Requirements for fire alarm systems in general states almost the same recommendations as the EN 54-14, but it is more detailed in some applications - for example, siting the detector below the pitched roof or in racked warehouses.

British standard BS 5839 Part 1 Code of practice for design, installation, commissioning and maintenance has different solutions for different types of systems: L(ife), P(roperty), etc., depending on what kind of object is under protection.

Russian standard НПБ 88 Установки пожаротушения и сигнализации. нормы и правила проектирования has rules that are largely restrictive compared to the other

Received May 3, 2017 / Accepted August 29, 2017

Corresponding author: Milan Blagojević

Faculty of Occupational Safety, Čarnojevića 10a, 18000 Niš, Serbia

E-mail: milan.blagojevic@znrfak.ni.ac.rs 
standards. For some applications there are no rules at all, but the standard refers to the manufacturer's documentation.

US standard NFPA 72 National Fire Alarm and Signalling Code is the most detailed and most accurate one, but on the other hand requires a designer with a higher level of knowledge and some of the solutions are largely different from European rules.

The simplest application of fire detection system related to arrangement of point fire detectors are corridors or narrow places. Although rules for this type of application originate from basic rules for siting and spacing of point type fire detectors, mentioned standards state different recommendations.

\section{BASIC RUles FOR Siting AND SpaCING OF POINT SMOKE DETECTORS}

It is well known that the number of fire detectors in the room is obtained by dividing the area of the room with the area of coverage of individual detector. By doing that, three types of situations may occur. The first one is the situation when the number of detectors is not enough, which can lead to some unprotected parts of the room. In the second approach, we can always increase the number of detectors above the required ones, but the question is who will pay for it. The investor will certainly not be satisfied with our design. Finally, the third situation is perfect square arrangement of detectors which is achieved by overlapping of individual coverage areas and the amount of $1 / 4$ of individual coverage area. Thus, the three most important parameters that standards should define are: $A$ - Area of coverage, $r-$ Radius and $S$ - Maximum distance between individual detectors, figure 1 .

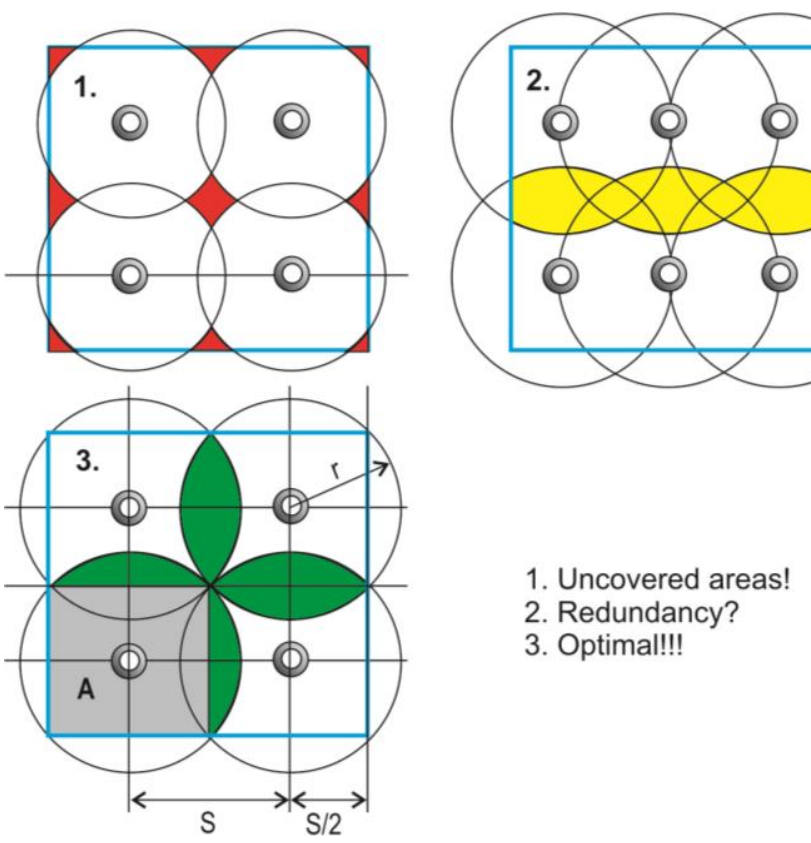

Fig. 1 Possible distributions of smoke point fire detectors 
European standard EN 54-14 generally permits the use of these detectors to a height of $11 \mathrm{~m}$, with a coverage radius of $7.5 \mathrm{~m}$. In practice, an area of coverage greater than 80 $\mathrm{m}^{2}$ is rarely used, but this radius in essence, gives a coverage area of individual detectors even $112 \mathrm{~m}^{2}$.

The German standard gives radius and coverage area through curves depending on the slope of the ceiling. Notice that there is a maximum permissible height of $12 \mathrm{~m}$, and that for the same radius as in the EN 54-14, area of coverage is less $-100 \mathrm{~m}^{2}$, not $112 \mathrm{~m}^{2}$.

The rules in British standard are similar to the previous ones, while the Russian standard is the less flexible, because it allows the maximum coverage area of $85 \mathrm{~m}^{2}$. Instead of the radius of coverage, Russian Standard gives the maximum distance between two detectors of $9 \mathrm{~m}$, which is less than the European - this distance in accordance with EN 54-14 is $10.6 \mathrm{~m}$.

The American standard has a different approach. According to this standard, in the circle that represents an area of covering of smoke detector, rooms with the largest surface area of about $80 \mathrm{~m}^{2}$ can be placed and a series of rectangles with a smaller surface area. This means that the standard radius is $9.1 \mathrm{~m}$. Further, standard recommends a virtual division of the room in the case of rooms with complex geometry. It is necessary to calculate the required number of detectors and the maximum allowable distance for each of the virtual area.

The basic rules for siting and spacing of point heat and smoke detectors according to EN 54-14 are shown in Table 1 and figure 1.

Table 1 EN 54-14 - heights and radii

\begin{tabular}{lcccccc}
\cline { 2 - 6 } Legend: & \multicolumn{7}{c}{ Ceiling height [m] } \\
\cline { 2 - 7 } NN - Not normally used in the range & \multicolumn{7}{c}{$>4.5$} & $>6$ & $>8$ & $>11$ & $>25$ \\
NS - Not suitable for use in the range & $\leq 4.5$ & $\leq 6$ & $\leq 8$ & $\leq 11$ & $\leq 25$ \\
\hline Type of detector & 5 & 5 & 5 & NN & NS & NS \\
\hline Heat detector EN 54-5 Class 1 & 7.5 & 7.5 & 7.5 & 7.5 & NN & NS \\
Smoke detector EN 54-7 &
\end{tabular}
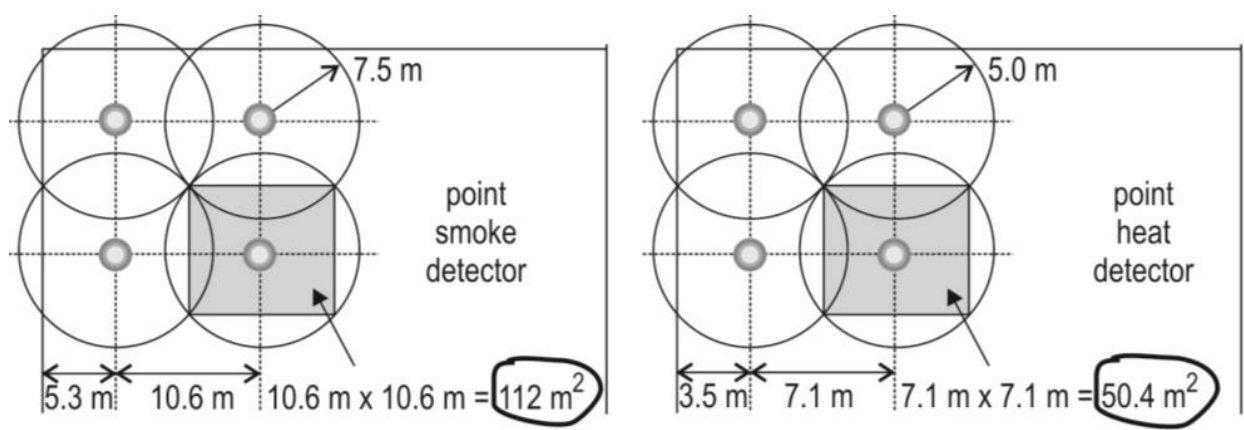

Fig. 2 Areas of coverage and radii for point smoke and heat detectors according to EN 54-14 


\section{CORRIDORS AND NARROW ROOMS}

In practice, fire alarm system designer can rarely meet with ideal situations as shown in figure 1. The interior of buildings depending on their purpose very often requires the application of special rules for siting. There are many special cases for siting of fire detectors, and the most often case refers to the narrow hallways and rooms. Here we already have the first problem, and that is the answer to the question "What is corridor", or "Which is the maximum width of the room in order to be considered as a corridor"?

The European standard does not define the corridor, only states that if the room is narrower than $1.2 \mathrm{~m}$, detector should be mounted within the middle third of the width.

Unlike the European, the German standard precisely defines that the corridor is the room of less than $3 \mathrm{~m}$ in width and gives rules for the distance between point-type smoke detectors. Smoke detectors can be located $15 \mathrm{~m}$ apart from each other, in case of coincidence detection type B up to $11 \mathrm{~m}$ or $7.5 \mathrm{~m}$ when triggering fire extinguishing systems.

According to the British standard, corridors are wider than the rest of European countries; a corridor is the room of less than $5 \mathrm{~m}$ in width. The standard does not provide specific rules, but only the formula for the calculation radius of detector, as follows: $(5 \mathrm{~m}$ $-w) / 2+7.5[\mathrm{~m}]$.

Based on the formula, it is obvious that if the corridor is $3 \mathrm{~m}$ wide, the radius will increase by $1 \mathrm{~m}$. That is, we get $8.5 \mathrm{~m}$ for the smoke detector.

The Russian standard does not give specific recommendations, except that for smoke detectors mutual distance in the corridor can be increased 1.5 times, which is almost the same as in the German standard (maximum distance is $9 \mathrm{~m} \times 1.5$ for room height up to $3.5 \mathrm{~m})$.

NFPA 72 defines corridor as room of less than $15 \mathrm{ft} .(4.6 \mathrm{~m})$ without further recommendations for spacing spot-type detectors. In other words, a corridor $10 \mathrm{ft}(3.0 \mathrm{~m})$ wide and up to $82 \mathrm{ft}(25.0 \mathrm{~m})$ long can be covered with two $30 \mathrm{ft}(9.1 \mathrm{~m})$ spot-type detectors.

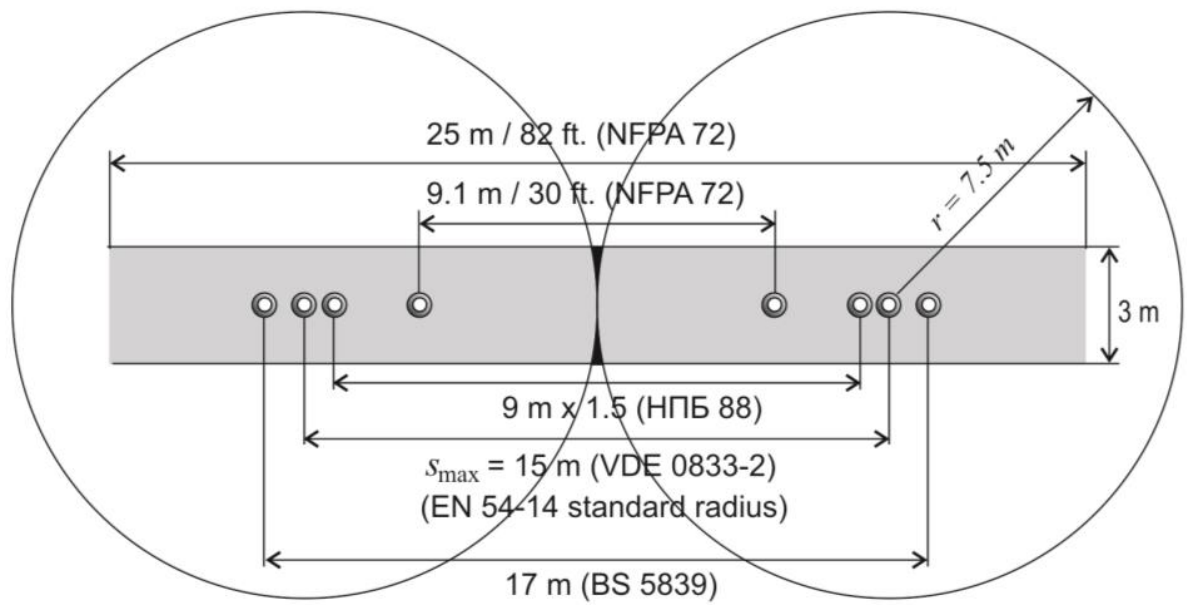

Fig. 2 Distances between smoke point detectors in corridors 
From fire detection system designer's point of view, it is interesting to find how these differences affect detectors response time. In order to investigate this problem, it is made we made a simulation model for a corridor which is covered by point smoke detectors according to the previous rules in five standards.

\section{Test Methods FOR Fire Detectors Sensitivity IN StANDARD EN 54}

European standard EN 54 Fire detection and alarm systems in document Part 9: Test fires for fire detectors describes test fires which are intended to represent fires that can occur in the real world and, on the other hand, represent tests for fire detector performance. The response of the detectors subjected to test fires is the most important factor which determines arrangement and distribution of fire detectors in order to detect fire in an early stage. Also, in this way it is possible to check response behaviour of whole detection system. Average and maximum heat release rates of standard test fires are relatively small, as shown in Table 2.

Table 2 Heat release rates of TF1-TF6

\begin{tabular}{cccc}
\hline Test fire & $\begin{array}{c}\text { Average consumption } \\
\text { rate }[\mathrm{g} / \mathrm{s}]\end{array}$ & $\begin{array}{c}\text { Average heat release } \\
\text { rate }[\mathrm{kW}]\end{array}$ & $\begin{array}{c}\text { Maximum heat release } \\
\text { rate }[\mathrm{kW}]\end{array}$ \\
\hline TF1 & 2.70 & 56 & 145 \\
TF2 & 0.11 & 2.3 & 3.8 \\
TF3 & 0.19 & 3.2 & 3.6 \\
TF4 & 1.20 & 30 & 84 \\
TF5 & 3.10 & 150 & 214 \\
TF6 & 4.00 & 120 & 125 \\
\hline
\end{tabular}

For this reason, the simulation described in this paper has been made for small initial mass and energy density, that is, for burners of $1 \mathrm{~kW} / \mathrm{m}^{2}, 3 \mathrm{~kW} / \mathrm{m}^{2}, 5 \mathrm{~kW} / \mathrm{m}^{2}$ and $35 \mathrm{~kW} / \mathrm{m}^{2}$, as the first parameter, and for ceiling height which is very significant and limiting factor for this type of consideration, as the second parameter. The main goal of the simulation is to investigate the differences between various standards rules, and consequently, the distance between detectors and site of fire, as well as the influence on response time of detectors.

\section{SIMULATION MODEL}

Simulation model was created in PyroSim software, version 2012, which presents a graphical user interface for the Fire Dynamics Simulator (FDS). FDS models are able to present smoke, temperature, carbon monoxide $(\mathrm{CO})$, and other fire products. Simulation software presents inevitable tool in fire protection systems design and many other calculations. Of course, for every simulation, it is needed to create simulation model with appropriate dimensions, materials, location of burner and heat release rate and other simulation conditions.

For simulation model a corridor in shape $T$ was chosen, which means that, independently of mentioned rules, one smoke detector will be located at intersection of 
corridor. According to this position, the location of other point smoke detectors was chosen. One section of corridor is $42 \mathrm{~m}$ long, the second one is $25 \mathrm{~m}$ long, the width of the corridor is $3 \mathrm{~m}$ and the height is $3.2 \mathrm{~m}$. Positions of all detectors, i.e. $s_{\max }$, are calculated according to the rules of standards measured from the detector located at intersection.

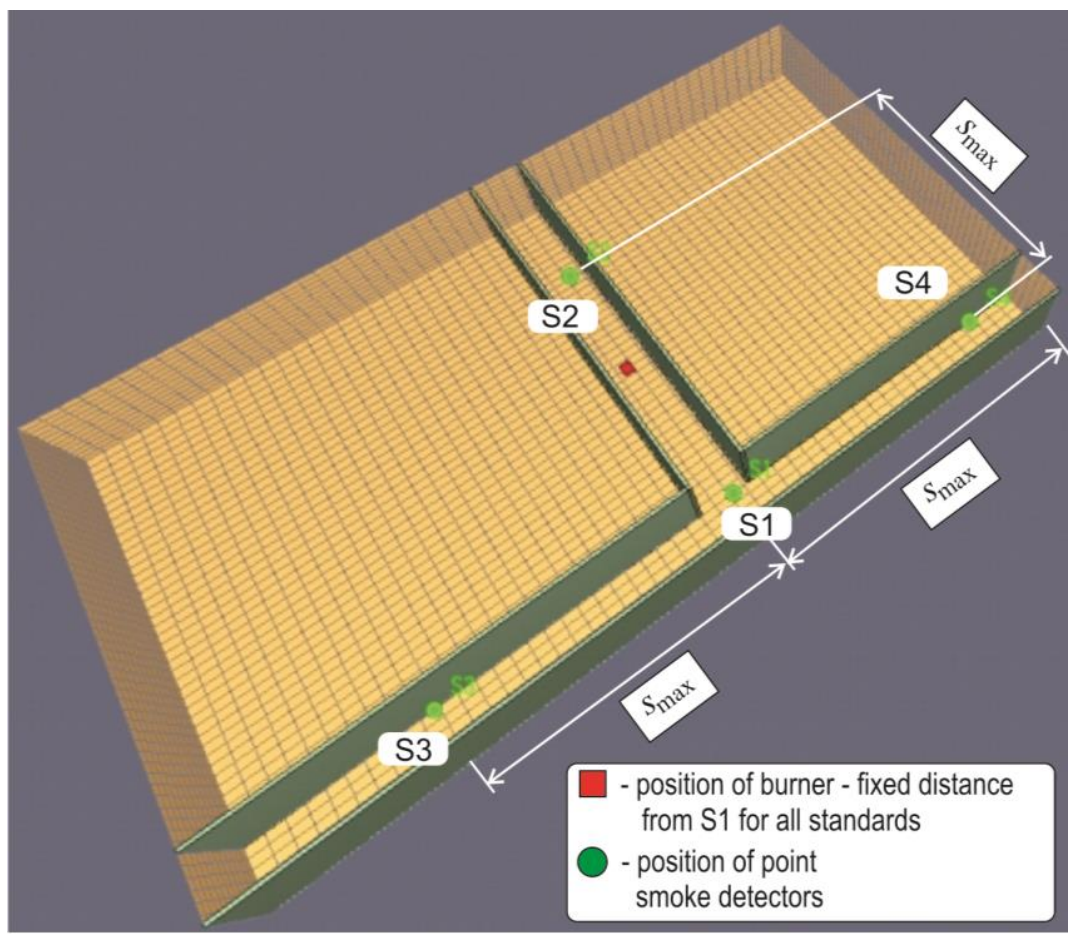

Fig. 3 Simulation model with positions of burner and detectors

For each ceiling height and for each burner the simulation's time was set on 500 seconds. The ambient conditions in realized simulations were normal (temperature, humidity and pressure). The alarm threshold for every smoke detector was set to 3,28 $\% / \mathrm{m}$. The smoke detectors arrangement for was different for each standard. For the EN 54-14 and VDE 0832-2 standards the distance between smoke detectors was $15 \mathrm{~m}$. For BS 5839-1 standard the distance between smoke detectors was $17 \mathrm{~m}$. For НПБ 88 standard the distance between smoke detectors was $13.5 \mathrm{~m}$ and for NFPA 72 standard, the distance between smoke detectors was $9.1 \mathrm{~m}$.

\section{SiMULATION RESULTS AND ANALISYS}

The simulations were made for ceiling heights of $4.5 \mathrm{~m}, 6 \mathrm{~m}$ and $8 \mathrm{~m}$ and burners of 1 $\mathrm{kW} / \mathrm{m}^{2}, 3 \mathrm{~kW} / \mathrm{m}^{2}, 5 \mathrm{~kW} / \mathrm{m}^{2}$ and $35 \mathrm{~kW} / \mathrm{m}^{2}$ for each ceiling height. Complete data for all simulations would take up a lot of space, so, here an example of simulation for $35 \mathrm{~kW} / \mathrm{m}^{2}$ burner and ceiling height of $4.5 \mathrm{~m}$ is shown. 
Table 3 Detectors response times

\begin{tabular}{lcrrr}
\hline Standard & S1 & S2 & S3 & \multicolumn{1}{c}{ S4 } \\
\hline EN & 40.2 & 26.66 & 100.3 & 101.2 \\
VDE & 40.2 & 26.66 & 100.3 & 101.2 \\
BS & 40.2 & 28.66 & 118.66 & 118.89 \\
HПБ & 40.2 & 25.21 & 100.87 & 100.65 \\
NFPA & 40.2 & 19.33 & 76.66 & 76.12 \\
\hline
\end{tabular}

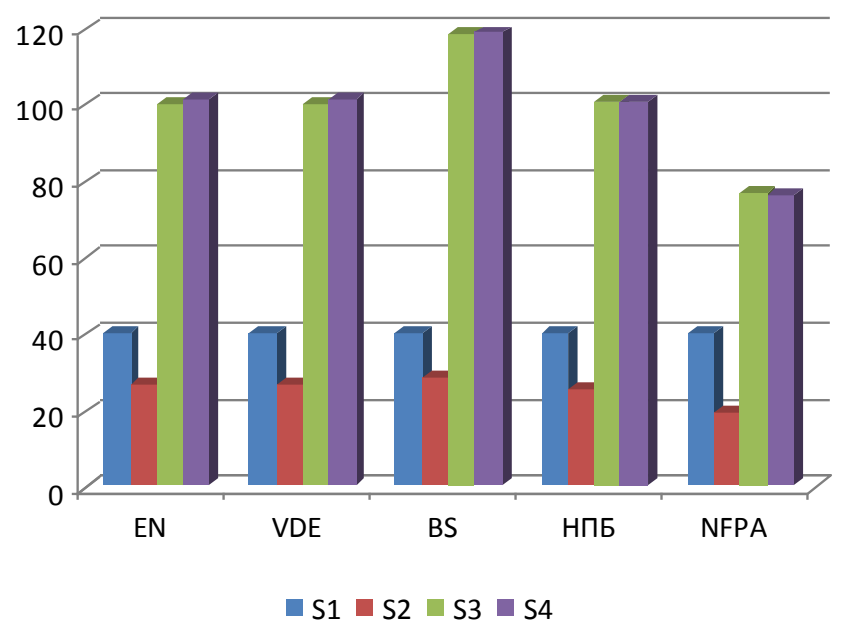

Fig. 4 Simulation for $35 \mathrm{~kW} / \mathrm{m}^{2}$ burner and height of the ceiling of $4.5 \mathrm{~m}$

The distance of a burner from a detector S1 was the same for all standards - on the edge of detector's area of coverage, so it is was interesting to evaluate the differences in standards taking into consideration influence on response time of detectors S2, S3 and S4 which positions are set according to maximal distance between detectors in corridors defined by standards.

Table 4 Response times of detector $\mathrm{S} 1$ in all standards

\begin{tabular}{lrrrr}
\hline $\mathrm{S} 1$ & $1 \mathrm{~kW} / \mathrm{m}^{2}$ & $3 \mathrm{~kW} / \mathrm{m}^{2}$ & $5 \mathrm{~kW} / \mathrm{m}^{2}$ & $35 \mathrm{~kW} / \mathrm{m}^{2}$ \\
\hline $\mathrm{h}=4.5 \mathrm{~m}$ & $438.38 \mathrm{~s}$ & $86.66 \mathrm{~s}$ & $73.33 \mathrm{~s}$ & $40.20 \mathrm{~s}$ \\
$\mathrm{~h}=6.0 \mathrm{~m}$ & & $86.56 \mathrm{~s}$ & $73.33 \mathrm{~s}$ & $43.10 \mathrm{~s}$ \\
$\mathrm{~h}=8.0$ & & $93.37 \mathrm{~s}$ & $80.29 \mathrm{~s}$ & $44.45 \mathrm{~s}$ \\
\hline
\end{tabular}

Obviously, the height of the ceiling has a little influence on detector response time except for a burner of $1 \mathrm{~kW}$. On the other hand, because of overlapping of detector S1 and S2 coverage areas, response times of detector S2 are a little shorter, and differentiate in mentioned standards. 
Table 5 Response times of detector S2 for $4.5 \mathrm{~m}$ height

\begin{tabular}{lcccc}
\hline S2 & $1 \mathrm{~kW} / \mathrm{m}^{2}$ & $3 \mathrm{~kW} / \mathrm{m}^{2}$ & $5 \mathrm{~kW} / \mathrm{m}^{2}$ & $35 \mathrm{~kW} / \mathrm{m}^{2}$ \\
\hline EN 54-14, VDE 0833-2 & $421.00 \mathrm{~s}$ & $60.04 \mathrm{~s}$ & $48.66 \mathrm{~s}$ & $26.66 \mathrm{~s}$ \\
BS 5839-1 & $427.45 \mathrm{~s}$ & $64.66 \mathrm{~s}$ & $51.33 \mathrm{~s}$ & $28.66 \mathrm{~s}$ \\
NPB 88 & $279.06 \mathrm{~s}$ & $53.56 \mathrm{~s}$ & $46.80 \mathrm{~s}$ & $25.21 \mathrm{~s}$ \\
NFPA 72 & $165.50 \mathrm{~s}$ & $41.30 \mathrm{~s}$ & $33.56 \mathrm{~s}$ & $19.33 \mathrm{~s}$ \\
\hline
\end{tabular}

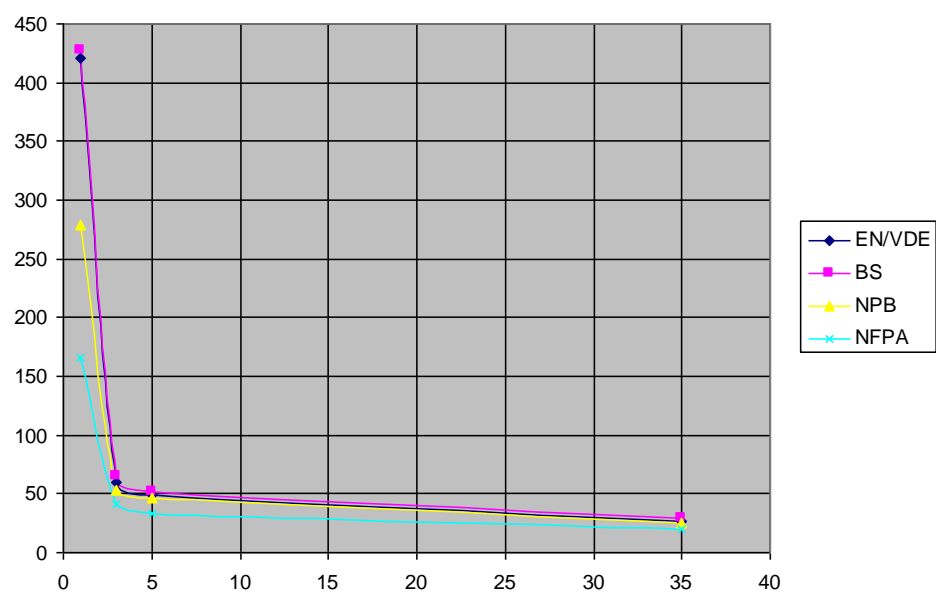

Fig. 5 Response times of detector S2 for $4.5 \mathrm{~m}$ height

Table 6 Response times of detector S2 for $6.0 \mathrm{~m}$ height

\begin{tabular}{lcccc}
\hline S2 & $1 \mathrm{~kW} / \mathrm{m}^{2}$ & $3 \mathrm{~kW} / \mathrm{m}^{2}$ & $5 \mathrm{~kW} / \mathrm{m}^{2}$ & $35 \mathrm{~kW} / \mathrm{m}^{2}$ \\
\hline EN 54-14, VDE 0833-2 & & $66.72 \mathrm{~s}$ & $60.00 \mathrm{~s}$ & $33.36 \mathrm{~s}$ \\
BS 5839-1 & & $67.56 \mathrm{~s}$ & $61.34 \mathrm{~s}$ & $34.12 \mathrm{~s}$ \\
NPB 88 & $165.51 \mathrm{~s}$ & $66.66 \mathrm{~s}$ & $56.66 \mathrm{~s}$ & $32.12 \mathrm{~s}$ \\
NFPA 72 & $140.89 \mathrm{~s}$ & $40.10 \mathrm{~s}$ & $34.20 \mathrm{~s}$ & $20.10 \mathrm{~s}$ \\
\hline
\end{tabular}

Table 7 Response times of detector $\mathrm{S} 2$ for $8.0 \mathrm{~m}$ height

\begin{tabular}{|c|c|c|c|c|}
\hline $\mathrm{S} 2$ & $1 \mathrm{~kW} / \mathrm{m}^{2}$ & $3 \mathrm{~kW} / \mathrm{m}^{2}$ & $5 \mathrm{~kW} / \mathrm{m}^{2}$ & $35 \mathrm{~kW} / \mathrm{m}^{2}$ \\
\hline EN 54-14, VDE 0833-2 & & $70.32 \mathrm{~s}$ & $61.21 \mathrm{~s}$ & $32.98 \mathrm{~s}$ \\
\hline BS 5839-1 & & $81.23 \mathrm{~s}$ & $72.81 \mathrm{~s}$ & $40.67 \mathrm{~s}$ \\
\hline NPB 88 & & $67.10 \mathrm{~s}$ & $53.56 \mathrm{~s}$ & $30.11 \mathrm{~s}$ \\
\hline NFPA 72 & & $43.78 \mathrm{~s}$ & $40.09 \mathrm{~s}$ & $24.26 \mathrm{~s}$ \\
\hline
\end{tabular}




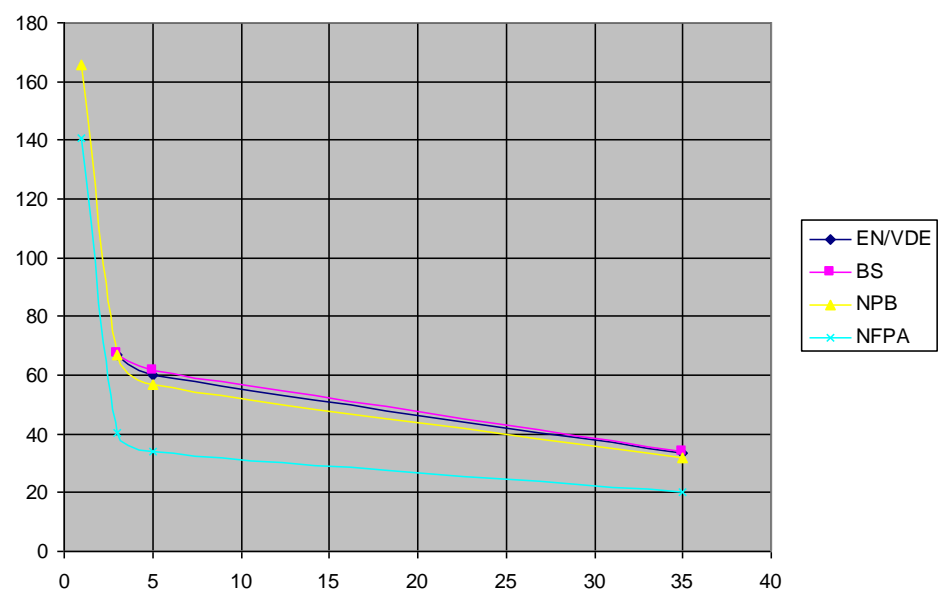

Fig. 6 Response times of detector $\mathrm{S} 2$ for $6.0 \mathrm{~m}$ height

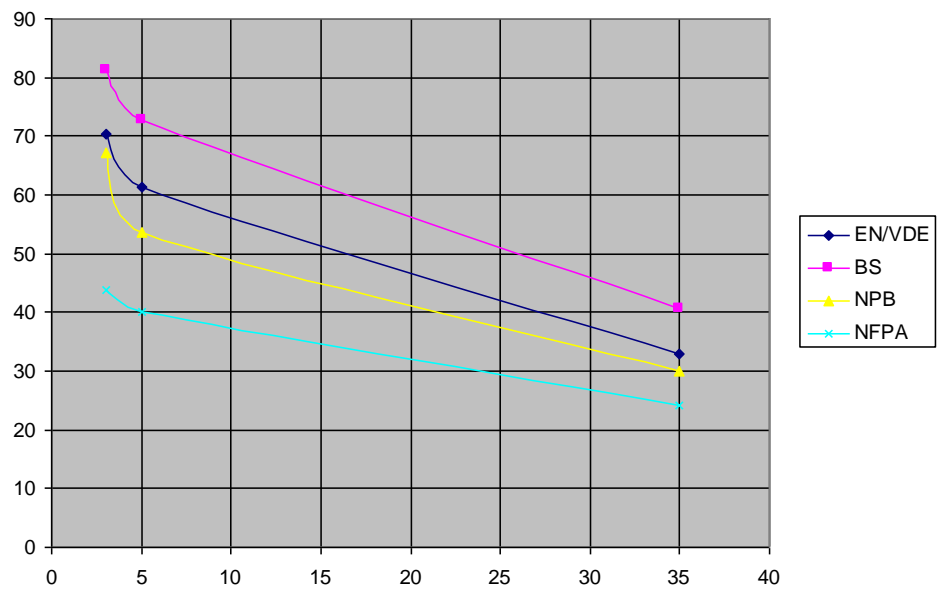

Fig. 7 Response times of detector S2 for $8.0 \mathrm{~m}$ height

Regardless of the fact that described simulations present simplification of fire in the sense of fire burns at a steady state, there are two basic conclusions based on these simulations from point of view of fire detection system. The first one is crucial for an early warning: only the NFPA rules, as well as the rules from the Russian standard provide detection of fires which are characterized by small initial mass and energy density. This conclusion is especially valid for slow smoldering fires, such as test fires TF2 and TF3 with week air flow. The second conclusion is that response times of nearest detectors for fire loads beyond $35 \mathrm{~kW} / \mathrm{m}^{2}$ are almost equal independently of the rules in various standards, especially for room heights up to $6 \mathrm{~m}$. 


\section{CONCLUSION}

As it might be expected, reducing the distance between the detectors, and therefore the distance from a detector to a possible site of fire, leads to smaller detector response. However, a couple of questions arise: how decrease of distance between detectors affect the reliability and response time of the whole system, and consequently the moment of the beginning of extinguishing, that is on activating stationary extinguishing system and activating evacuations systems. In our opinion, the rules from EN 54-14 and VDE 0833-2 are completely satisfactory for most applications in practice. Finally, a detailed analysis demands to take into account response time index RTI for smoke detector under consideration in every particular application.

\section{REFERENCES}

1. Blagojević M., Alarmni sistemi, monografija, 2. ispravljeno i dopunjeno izdanje, Fakultet zaštite na rad u Nišu, ISBN 978-86-6093-070-7, 2015.

2. Blagojevic M., Jevtic R., Ristic D., On the correct number and arrangement of point smoke detectors, Požární ochrana 2015 Sborník přednášek XXIV. ročníku mezinárodní konference, Technické univerzity Ostrava, ISBN 978-80-7385-169-7, ISSN 1803-1803, 2015., pp. 7-11

3. BS 5839-6: Fire detection and alarm systems for buildings. Code of practice for the design and installation of fire detection and alarm systems in dwellings, 2004.

4. DIN VDE 0833-2, Alarm systems for fire, intrusion and hold up, Requirements for fire alarm systems, 2009.

5. Grosshandler W., A review of measurements and candidate signatures for early fire detection, NISTIR 5555, BFRL NIST, 1995.

6. EN 54-14: Fire detection and fire alarm systems, Guidelines for planning, design, installation, commissioning, use and maintenance, 2004.

7. НПБ 88-2001: Нормы пожарной безопасности- Установки пожаро-тушения и сигнализации. Нормы и правила проектирования, Министерство Внутренних Российской Федерации, 2001.

8. NFPA 72: National Fire Alarm and Signaling Code, 2016 Edition, NFPA, 2016.

\section{KOMPARATIVNA ANALIZA PRAVILA ZA POSTAVLJANJE DETEKTORA DIMA U HODNICIMA}

$U$ radu je data komparativna analiza pravila za postavljanje detektora dima u hodnicima $i$ uskim prostorijama pet vodećih standarda u svetu za projektovanje sistema za dojavu požara: EN 54-14, VDE 0833-2, BS 5839-1, НПБ 88 and NFPA 72. Razlog za ovakvu analizu je očigledan: evropski standard čak ne definiše pojam hodnika za razliku od drugih standarda koji u manjoj ili većoj meri definišu pravila za postavljanje. Analiza je urađena korišćenjem programskog paketa PyroSim software, koji predstavlja grafički korisnički interfejs paketa Fire Dynamics Simulator (FDS).

Ključne reči: tačkasti detektori požara, hodnici, simulacija, PyroSim 